\title{
PEMANTAU LOKASI BENDA BERGERAK BERBASIS WEB DENGAN MENGGUNAKAN TEKNOLOGI GPS DAN 3G
}

\author{
Lukas Tanutama, Daniel P. Hutabarat \\ Computer Engineering Department, Faculty of Engineering, Binus University \\ Jl. K.H. Syahdan No. 9, Palmerah, Jakarta Barat 11480 \\ lukast12@binus.edu, dhutabarat@binus.edu
}

\begin{abstract}
This research aims to develop a system to monitor moving objects via web. The moving objects could be owned by individuals or company and can be used and managed independently. The system consists of three subsystems namely Mobile Geographical Location Sender (MGLS), Main Geographical Location Information Control (MGLIC), and Geographical Location Information User (GLIU). MGLS functions as geographical sensor. It retrieves GPS data and sends periodically to MGLIC as the main controller via $3 G$ service. MGLIC is the receiving server and designed as web server as well. The web server is the host of a control application that processes GPS data that was sent by MGLS. The data is stored in a database and is centrally displayed. The processed information can also be used by GLIU, as another user that needs the information. Experimental test shows that the system can function according to the design.
\end{abstract}

Keywords: moving object, GPS, $3 G$

\begin{abstract}
ABSTRAK
Penelitian ini bertujuan mengembangkan suatu sistem yang untuk memantau benda bergerak melalui web. Benda dapat dimiliki pribadi ataupun perusahaan, dan dapat digunakan serta dikelola secara mandiri. Sistem ini terdiri atas tiga subsistem yaitu Pengirim Bergerak Lokasi Geografis (PBLG) atau Mobile Geographical Location Sender (MGLS), Pengendali Utama Informasi Lokasi Geografis (PUILG) atau Main Geographical Location Information Control - MGLIC), dan Pengguna Informasi Lokasi Geografis (PILG) atau (Geographical Location Information User- GLIU). PBLG berfungsi sebagai sensor geografis yang mengambil data lokasi geografis dari GPS untuk kemudian mengirimkannya ke PUILG sebagai pusat pengendali melalui layanan 3G. PUILG bekerja sebagai server penerima dan juga dirancang sebagai server web. Server web ini mengatur aplikasi pengendali yang bertugas mengolah data GPS yang dikirimkan oleh PBLG. Data tersebut disimpan dalam database dan tampil visual secara terpusat. Informasi yang telah diolah juga dapat digunakan PILG sebagai pengguna lain yang memerlukan informasi tersebut. Pengujian ekperimental menunjukkan bahwa sistem yang dikembangkan ini dapat berfungsi sesuai dengan rancangan.
\end{abstract}

Kata kunci: benda bergerak, GPS, $3 G$ 


\section{PENDAHULUAN}

Keberadaan benda bergerak seperti kendaraan roda dua, roda empat, maupun benda lain baik milik pribadi maupun perusahaan kerap kali menjadi pertanyaan bagi setiap pemiliknya. Sebagai contoh, perusahaan yang bergerak di jasa pengantaran peti kemas ingin mengetahui informasi geografis keberadaan kendaraannya pada waktu tertentu pada saat kendaraan tersebut sedang mengantar peti kemas ke lokasi yang telah ditentukan. Demikian pula untuk mengetahui keberadaan peti kemas itu sendiri atau benda lain yang besar kemungkinannya berpindah tempat sehingga perlu dipantau pergerakannya atau dilacak keberadaannya. Selain itu juga, banyak perusahaan memberikan layanan jasa antar barang maupun dokumentasi dengan menggunakan kendaraan roda dua dimana informasi geografis keberadaan kendaraan tersebut sangat berarti bagi perusahaan. Perusahaan taksi atau penyewaan kendaraan roda empat maupun kendaraaan pengangkut barang perlu mengetahui keberadaan kendaraan baik untuk keperluan pengendalian maupun memberikan layanan pada pelanggan yang memerlukan dengan mengetahui kendaraan yang posisinya dekat dengan pelanggan. Baik perorangan ataupun pribadi memiliki kebutuhan untuk mengetahui keberadaan lokasi geografis benda bergerak.

Benda bergerak tidak terbatas pada kendaraan tetapi juga anak kecil, orang tua, bahkan dalam keadaan tertentu diri sendiri. Keberadaan lokasi geografis ini mempunyai arti besar untuk keperluan pelacakan dan pencarian maupun koordinasi menuju lokasi tempat yang telah disepakati. Ketersediaan informasi ini akan sangat membantu seseorang ketika ingin mengetahui keberadaan sebuah benda yang bergerak. Informasi keberadaan benda bergerak ini sangat bermanfaat dalam banyak hal, misalnya, untuk pelacakan anak bawah usia atau orang lanjut usia maupun benda lain yang dicurigai hilang. Sebenarnya telah terdapat sejumlah perusahaan yang bergerak di bidang jasa pemantauan kendaraan bagi perusahaan transportasi, logistik, catering dan sebagainya. Pelanggan perusahaan jasa pemantauan ini merupakan perusahaan dalam operasional kesehariannya menggunakan banyak kendaraan dalam menjalankan usahanya. Informasi lokasi geografis dari setiap kendaraan yang ada sangatlah penting untuk dapat diolah dan digunakan untuk menjalankan suatu proses lanjutan tertentu. Kebutuhan layanan informasi geografis sebenarnya sudah terlayani tetapi sangat bergantung pada operator jasa layanan pemantauan dan pelacakan, khususnya kendaraan beroda empat atau lebih seperti bis, truk, dan sebagainya.

Bagi konsumen perorangan kebutuhan layanan informasi geografis bisa sangat beragam. Keragaman ini disesuaikan dengan kebutuhan dari setiap konsumen. Seorang konsumen perorangan atau usaha kecil dan menengah selain menggunakan layanan ini untuk memantau lokasi operasional kendaraannya sehari-hari, juga untuk memantau lokasi benda bergerak yang harus diketahui keberadaannya dalam menjalankan kegiatan usaha. Konsumen tertentu juga memerlukan layanan sebagai sarana untuk melacak lokasi mobil pribadi dalam hal keamanannya. Kebutuhan konsumen perorangan pada layanan ini, untuk saat ini, terkendala oleh biaya jasa yang relatif mahal dan ketergantungan pada operator jasa layanan ini. Tuntutan konsumen perorangan juga merupakan salah satu hal yang harus diatasi. Konsumen sekarang mempunyai karakteristik mobilitas yang tinggi. Mobilitas ini menuntut layanan dengan fleksibilitas yang tinggi pula, sehingga diperlukan sebuah layanan yang dapat diakses kapanpun dan dimanapun juga.

Mengacu kepada tuntutan di atas maka peneliti mengembangkan sistem yang terdiri atas alat pemantau benda bergerak yang ekonomis untuk konsumen perorangan maupun perusahaan, khususnya usaha kecil dan menengah, yang dapat di akses melalui web dan dapat digunakan secara mandiri. Mandiri mempunyai arti swakelola yaitu tidak bergantung pada perusahaan jasa layanan pelacakan dan pemantauan. Dengan adanya ragam kebutuhan yang dapat muncul dari konsumen perorangan dan perusahaan terhadap kebutuhan informasi geografis dan dengan melihat kepada pemanfaatan teknologi 3G, maka alat pemantau benda bergerak berbasis web ini akan sangat membantu konsumen perorangan dan perusahaan dalam hal pemenuhan kebutuhan informasi geografis untuk proses lanjutan sekaligus mendukung pemanfaatan penggunaan teknologi 3G. 


\section{Global Positioning System}

Global Positioning System (GPS) adalah sebuah sistem yang dapat menunjukkan posisi lokasi geografis suatu benda di permukaan bumi secara cepat. GPS ini merupakan sistem satelit navigasi untuk menentukan letak geografis suatu penerima sinyal satelit tersebut, Posisi geografis diberikan melalui sistem koordinat bujur dan lintang. Posisi ini diketahui melalui alat penerima yang dapat memberikan informasi mengenai koordinat lintang dan bujur yang diberikan oleh sinyal GPS yang diterimanya. Koordinat ini diperoleh melalui perhitungan yang telah dibakukan. GPS sendiri pada awalnya digunakan oleh Amerika Serikat untuk keperluan militer, namun sekarang sinyal dari susunan satelit tersebut dapat dipergunakan oleh siapapun dengan bebas, sehingga berbagai aplikasi yang memanfaatkan kemampuan mengetahui lokasi geografis ini dapat berkembang. Penerima sinyal satelit GPS mempunyai ukuran yang kecil bahkan dapat integrasikan menjadi bagian yang tak terpisahkan dari telepon seluler, khususnya generasi smartphone. GPS sebagai sistem navigasi satelit, menggunakan jaringan 24 satelit dalam orbitnya. GPS berfungsi terus pada kondisi cuaca apapun, dan tidak bergantung pada waktu dan tempat. Keterbatasannya terletak pada penerimaan sinyal GPS khususnya sifat gelombang elektromaknetik di dalam ruang tertutup (Alde et al, 2011).

Secara sistem GPS terbangun dari beberapa subsistem, yaitu subsistem satelit di angkasa, subsistem pengendali dan subsistem penerima atau pengguna. Subsistem satelit terdiri atas 24 satelit yang beroperasi dalam enam orbit dengan ketinggian sekitar $20000 \mathrm{~km}$. Terdapat 21 satelit yang aktif dan tiga buah satelit sebagai cadangan. Susunan orbit tertentu telah diatur sedemikian rupa sehingga satelit GPS dengan sinyal terhubung yang dapat diterima berjumlah antara empat sampai delapan buah satelit. Setiap satelit akan kembali ke titik awal setiap 12 jam. Subsistem pengendali dikelola sendiri oleh Amerika Serikat dengan lima stasiun pemantau dan antena yang tersebar di bumi ini. Subsistem pengendali ini melacak orbit satelit, lokasi, ketinggian dan kecepatan dari satelit. Sinyal dari satelit diterima, dilakukan koreksi dan dikirimkan kembali ke satelit. Koreksi data lokasi yang tepat dari satelit disebut dengan data ephemeris. Data ini akan dikirimkan kepada penerima. Subsistem penerima terdiri atas dari antena, pengolah sinyal, dan antarmuka yang sesuai dengan kebutuhan pengguna. Pesan navigasi GPS terdiri atas tiga komponen yaitu, bagian pertama yang berisi tanggal dan waktu GPS, status satelit, bagian kedua disebut data ephemeris berisi informasi orbit yang memungkinkan penerima melakukan perhitungan posisi satelit dan bagian ketiga disebut almanak yang berisi informasi status semua satelit, lokasi dan Pseudo Random Number (PRN).

Penerima dipasarkan secara komersial oleh perusahaan yang bergerak dalam segmen produk ini. Satelit akan memancarkan data ephemeris dan almanak yang diterima secara periodik oleh penerima. Data almanak berisikan perkiraan lokasi satelit yang dipancarkan terus menerus oleh satelit. Data ephemeris dipancarkan oleh satelit, dan berlaku untuk sekitar empat sampai enam jam. Untuk menunjukkan koordinat sebuah titik (dua dimensi), penerima memerlukan paling sedikit tiga buah sinyal satelit. Untuk mengetahui data ketinggian sebuah titik, diperlukan tambahan sinyal dari satu buah satelit lagi. Penerima akan melakukan perhitungan untuk mengetahui lokasinya. Makin banyak jumlah sinyal satelit yang diterima oleh sebuah alat penerima maka akan semakin tepat perhitungan posisinya. Penerima GPS memperoleh sinyal dari beberapa satelit yang mengorbit bumi. Penerima GPS harus menerima paling sedikit tiga buah sinyal satelit untuk menghitung koordinat letak di bumi yaitu lintang dan bujur. Bila digunakan sinyal dari empat atau lebih satelit penerima maka dapat ditentukan ketinggi di atas permukaan bumi.

Posisi geografis ini dapat digunakan untuk mengembangkan berbagai aplikasi khususnya yang berkaitan dengan data ini. Aplikasi yang sangat berkembang ialah aplikasi yang berkaitan dengan benda bergerak baik yang sendiri maupun yang bergerak karena dibawa oleh benda lain yang bergerak. Mengingat bahwa system telekomunikasi yang dominan sekarang ini adalah system telepon bergerak, fasilitas GPS juga dibuat sebagai bagian tak terpisahkan dari pesawat telepon bergerak (Chandran,2013; Gruber, 2011; Moloo, 2011). 


\section{Assisted-GPS}

Assisted GPS (A-GPS) merupakan sistem yang ditujukan untuk memperbaiki time-to-first-fix (TTFF) dari GPS. Sistem ini digunakan untuk telepon seluler yang dilengkapi dengan GPS. Operasi GPS tradisional hanya menggunakan sinyal langsung dari satelit. Seringkali sinyal langsung ini kualitasnya kurang memadai karena terjadinya multipath propagation maupun halangan lain. Penerima GPS memerlukan waktu untuk menetapkan lokasi saat mulai dijalankan. A-GPS dapat mengatasi masalah ini dengan mengambil data yang ada dalam jaringan komunikasi seluler. Untuk keperluan bantuan ini terdapat dua kategori yaitu Mobile Station Based (MSB) dan Mobile Station Assisted (MSA). MSB digunakan agar penerima mendapatkan sinyal satelit yang diperlukannya dengan cepat karena satelit yang berkaitan telah diketahui. MSA menggunakan kemampuan server untuk menghitung lokasi.

Sinyal GPS diberikan kepada server berikut waktunya untuk diolah menjadi koordinat lokasi. Kemampuan server memberikan kemudahan bagi GPS receiver pada perangkat seluler untuk memberikan lokasi yang tepat. A-GPS receiver akan menggunakan koneksi data untuk mendapatkan informasi GPS yang diperlukan dari server. Server A-GPS ini merupakan sistem milik Network Operator yang memiliki informasi satelit pada database-nya. Informasi ini dapat diperoleh melalui layanan seluler seperti CDMA, WCDMA dan sebagainya. Operasi A-GPS receiver dengan mode MSA akan menerima bantuan terutama berkaitan dengan akusisi dan waktu referensi. Operator seluler akan mengambil data GPS ke dalam servernya. Data ini bersama dengan data dari perangkat GPS dalam seluler akan diberikan ke server untuk dihitung posisinya dan dikembalikan ke receiver. Penerima dengan operasi MSB akan menerima data ephemeris, lokasi referensi dan waktu referensi dari A-GPS server. Data ini akan digunakan bersama dengan sinyal dari satelit untuk menentukan posisinya (Djuknic, \&Richton, 2001; Feng, \&Law, 2002; Zandbergen, 2009).

\section{Android}

Android merupakan sistem operasi open source yang bertumpu pada Linux sebagai landasan. Android terdiri dari atas sistem operasi, user interface dan juga program aplikasi. Android sekarang telah melakukan integrasi sejumlah aplikasi internet yang populer seperti Facebook, dan sebagainya. Setiap versi Android memiliki nama dan nomor versi. Versi dibedakan melalui API level. Untuk mengembangkan program aplikasi digunakan Android SDK selain itu terdapat Android developer tools (ADT) yang merupakan plug-in yang menghubungkan antara SDK dengan IDE eclipse yang dipakai oleh developer sehingga eclipse dapat membuat aplikasi dengan berbasis Android. Eclipse SDK adalah sebuah integrated development environment (IDE)

\section{Google Maps}

Location Based Service (LBS) mengacu kepada aplikasi yang memberdayakan pengetahuan posisi geografis perangkat bergerak untuk memberikan layanan. Lokasi dapat ditentukan secara visual ataupun dalam deskripsi teks. Lokasi spasial dapat direpresentasikan pada penggunaan sistem koordinat bujur dan lintang. Lintang didefinisikan sebagai 0-90 derajat utara atau selatan ekuator. Bujur sebagai 0-180 derajat barat atau timur dari meridian utama yang melewati Greenwich, Inggris. Ketinggian (altitude) direpresentasikan sebagai satuan meter di atas permukaan laut. Deksripsi teks didefinisikan sebagai lokasi jalan, yang mengandung nama kota, kode pos, dan sebagainya (Singhal, and Shukla, 2012).

Google Maps mapping service adalah sebuah online tool yang memberikan user berbagai fitur map seperti tampilan street maps, arahan kemudi point-to-point, dan jalur-jalur untuk mencari lokasi bisnis di berbagai kota. Dengan tambahan street map dan terrain view, satellite atau aerial views dapat memberikan tampilan yang mudah dipahami user dan dapat diakses siapa saja melalui koneksi daring. Untuk menampilkan peta dari Google Maps, diperlukan Google Maps API. Geocoding adalah sebuah proses konversi alamat ke dalam kordinat geografis lintang dan bujur yang dapat digunakan untuk 
menempatkan marker atau posisi pada map. Reverse Geocoding kebalikannya, yaitu adalah proses konversi dari kordinat geografis ke alamat yang mudah dimengerti.

\section{Layanan 3G}

Data lokasi geografis akan ditransmisikan ke pihak yang diperlukan. Mengingat bahwa benda akan terus menerus bergerak, data lokasi geografis ini juga harus disalurkan secara terus menerus atau secara waktu nyata. Sistem transmisi data harus mampu memenuhi persyaratan keberadaan sambungan yang tetap antara benda bergerak yang dilacak dan pelacaknya. Perubahan lokasi harus dapat dikomunikasikan dengan cepat dan tepat apalagi bila benda tersebut bergerak relatif cepat. Mengingat pergerakan benda yang relatif bebas, pengiriman data tidak dapat dilakukan melalui media transmisi konvensional yaitu kabel. Data lokasi geografis harus dapat dikirimkan mengikuti benda tersebut.

Media transmisi yang cocok dengan persyaratan ini adalah gelombang elektromaknetik. Dari berbagai layanan transmisi menggunakan gelombang elektromaknetik, yang sangat potensial untuk keperluan pelacakan ini adalah layanan 3G. Layanan 3G merupakan pengembangan layanan telepon seluler dengan kemampuan layanan komunikasi data yang dikhususkan ke sambungan ke Internet. Pelanggan layanan 3G dapat langsung masuk ke jaringan 3G untuk tersambung ke Internet. Pelanggan 3G akan tersambung ke Server yang ada di Internet. Pada saat ini sambungan langsung antar pelanggan tidak dapat dilakukan. Pelanggan hanya dapat terhubung ke suatu server yang ada di Internet. Informasi geografis harus dikirimkan ke server yang disediakan khusus untuk keperluan ini. 3G disini mengandung arti komunikasi selular generasi ketiga. 3G merupakan hasil evolusi komunikasi tradisional yang terutama berbentuk komunikasi suara menjadi komunikasi yang menuntut perrtukaran data yang besar, cepat dan mobil (Molisch, 2011; Talukder, 2011, Schiller, 2009).

ITU (Intenational Telecomunication Union) mendefisikan 3G (Third Generation) sebagai teknologi yang mempunyai kemampuan dalam penyaluran data dengan unjuk kerja antara lain memiliki kecepatan transfer data sebesar $144 \mathrm{kbps}$ pada kecepatan user $100 \mathrm{~km} / \mathrm{jam}$, memiliki kecepatan transfer data sebesar 384 kbps pada kecepatan berjalan kaki, serta memiliki kecepatan transfer data sebesar 2 Mbps pada untuk user yang tidak bergerak (stasioner). Dengan kecepatan transfer data antara $144 \mathrm{kbps}$ - 2 Mbps maka teknologi 3G dapat melayani layanan data broadband seperti internet, video on demand, music on demand, games on demand, dan sebagainya. 3G mempunyai beberapa kelebihan dalam hal komunikasi data yaitu berkecepatan tinggi dalam menyalurkan data serta mempunyai kemampuan always on atau selalu tersambung ke jaringan. Pengguna hanya perlu melakukan prosedur satu kali penyambungan ke jaringan dan selanjutnya akan tetap tersambung.

Data dapat langsung dikirimkan ke tempat tujuan yang tersambung ke Internet. Data hanya dapat dikirimkan ke server yang berada di Internet. Kapasitas atau kecepatan penyaluran data mencapai 2 Mbps untuk benda yang bergerak relatif lambat. Layanan yang diberikan dapat packet dan circuit-switched service. Efiensi spektrum yang bagus memungkinkan penggunaan secara maksimum bandwidth yang terbatas. Kemampuan yang ada pada teknologi 3G dapat dimafaatkan untuk berbagai hal yang sebelumnya terkendala oleh ketersediaan infrastruktur seperti untuk mengakuisisi data dan melakukan remote monitoring. Gruber et al. (2011) dalam publikasi hasil penelitiannya memaparkan tentang model remote data acquisition dan monitoring small wind turbine.

Pada penelitian ini Gruber et al. (2011) memanfaatkan teknologi 3G karena kecepatan transfer datanya yang cepat untuk monitoring yang berkelanjutan. Layanan data 3G terus berkembang sehingga kecepatan pengiriman data juga bertambah. Terkadang untuk membedakan satu layanan dengan layanan yang lain digunakan terminologi khusus seperti 3.5G atau HSDPA dan sebagainya. Perbedaan yang utama hanyalah menyangkut kemampuan transmisi data, tetapi prinsip komunikasi data harus ke server di Internet tidak berubah. Keuntungan lain dari layanan 3G ini berkaitan dengan 
perangkatnya. Perangkat yang mendukung 3G relatif mempunyai harga ekonomis, berukuran kecil, mudah didapat dan dapat diberi kecerdasan.

Penelitian ini bertujuan untuk mengembangkan sistem yang menerapkan pemanfaatan transmisi data 3G dan GPS untuk melacak benda bergerak baik secara waktu nyata maupun mengetahui pergerakan yang telah terjadi. Pelacakan ini tidak saja dapat dilakukan dari satu pusat pengendali tetapi juga antar benda bergerak itu sendiri. Transmisi data 3G ke Internet yang sekarang beroperasi adalah sambungan ke server yang juga tersambung di Internet. Server ini harus dikenali, baik melalui suatu Name Server atau IP address publik. Server yang dalam penelitian ini dikembangkan dalam penelitian ini dipanggil sebagai Pusat Pengendali terbangun atas Web Server dan Database. Semua komunikasi dilakukan melalui Internet ke server ini. Kemudahan komunikasi dapat diperoleh karena menggunakan browser yang dapat berkomunikasi dengan web server.

Manfaat yang diperoleh dari sistem ini ialah bagi pelaku usaha kecil maupun menengah yang ingin mengetahui letak geografis dari benda yang bergerak baik itu manusia, barang yang dikirimkan, kendaraan roda dua dan sebaginya. Lokasi geografis ini penting untuk layanan pada pelanggan maupun mengetahui efisiensi penggunaan waktu, bahan bakar dan keamanan dari benda bergerak tersebut. Sistem ini dapat dioperasikan tanpa memerlukan pihak ketiga. Pihak ketiga umumnya adalah operator jasa layanan pelacakan kendaraan niaga. Untuk pemakai individual dapat digunakan untuk meningkatkan pengamanan kendaraannya dengan mengetahui keberadaannya setiap saat. Data yang tersimpan dapat digunakan untuk mengetahui rute jalur yang ditempuh selama periode tertentu. Sistem dasar hasil penelitian ini dapat dikembangkan lebih lanjut ke aplikasi lain yang inovatif mengingat data yang tersimpan dalam database dari server serta sambungan melalui 3G yang selalu ada (always on).

\section{METODE}

Metodologi penelitian ini diawali dengan perancangan sistem secara umum, dilanjutkan dengan perancangan perangkat lunak untuk Location Sensor, perancangan pengendali utama, perancangan user mobil serta user tak bergerak. Proses perancangan dilanjutkan dengan proses seleksi komponen perangkat keras maupun perangkat lunak yang dapat memenuhi fungsi yang dirancang. Semua subsistem kemudian dibangun dan diuji secara tersendiri. Setelah tiap subsistem dapat berjalan sesuai dengan fungsi yang telah dirancang, subsistem disambungkan menjadi sistem yang dapat berfungsi melakukan pelacakan dan pemantauan keberadaan benda yang bergerak baik dari pusat pengendali maupun masing-masing benda tersebut. Evaluasi dilakukan untuk keseluruhan sistem.

\section{Perancangan System}

Sistem yang dikembangkan terdiri atas tiga subsistem yaitu Pengirim Bergerak Lokasi Geografis (PBLG), Pengendali Utama Informasi Lokasi Geografis (PUILG) dan Pengguna Informasi Lokasi Geografis (PILG). PBLG atau Mobile Geographical Location Sender (MGLS) dipasang pada benda bergerak ini sebagai Location Sensor. Dalam penelitian ini digunakan Mobile Station 3G yang mendukung Android dan mempunyai GPS. Mobile Station ini akan dilengkapi dengan perangkat lunak yang dapat mengirimkan hasil dari GPS ke Pengendali Utama (PUILG). Pengendali Utama merupakan Web Server yang tersambung ke Internet dan dapat dilengkapi dengan database yang sederhana. Pada bagian server, data yang diterima dari sensor disimpan dalam database.

Pengguna informasi lokasi geografis (PILG) statik dapat mengambil data koordinat dari server dan dapat ditampilkan pada suatu peta lokasi (dalam penelitian ini digunakan Google Map). Pengguna statik dapat menggunakan PC regular. Bila digunakan PC, sejumlah program aplikasi dapat 
dikembangkan sesuai dengan kebutuhan mengingat data telah tersimpan dalam database. Pengguna bergerak dapat menggunakan smartphone yang dilengkapi dengan Android beserta program aplikasi khusus. Secara diagram balok sistem ini dapat digambarkan sebagai berikut:

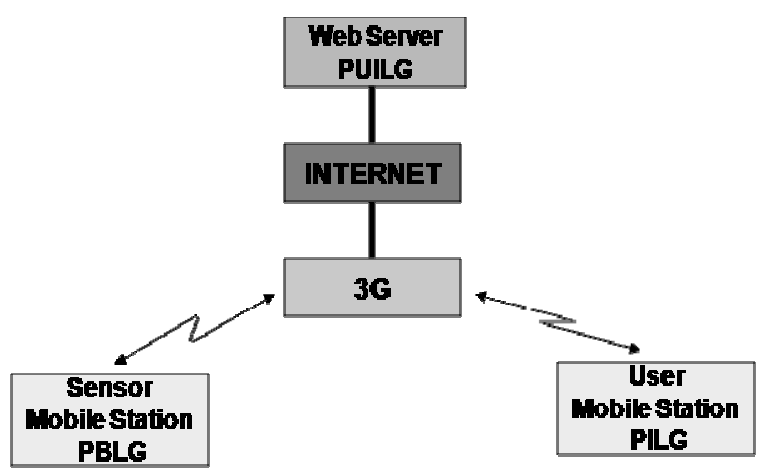

Gambar 1 Diagram Balok Sistem

\section{Perancangan Pengirim Bergerak Lokasi Geografis (PBLG)}

PBLG berfungsi sebagai Location Sensor. Fungsi ini dikembangkan oleh smartphone yang menggunakan Android sebagai Operating Systemnya. Untuk menjalankan sensor secara sempurna dilakukan terlebih dahulu proses inisialisasi atau update position gunanya menguji apakah transmisi data GPS berjalan dengan baik. Pada saat inisialisasi ini dikirimkan data kepada database melalui server. Data di database akan dibaca untuk mencari tahu apakah data yang dikirim dari Android sudah diterima oleh database server. Bila inisialisasi menunjukkan hasil yang memuaskan, Location Sensor ini akan melakukan fungsinya yaitu mengirimkan data tempat sekarang ke Pengendali Utama dengan menggunakan transmisi 3G.

Pengendali Utama adalah suatu Web Server yang dilengkapi dengan aplikasi penyimpanan data lokasi setiap benda bergerak yang dilengkapi dengan Location Sensor. Penentuan data lokasi atau pembacaan koordinat letak dilakukan secara periodik. Proses ini akan mengikuti langkah seperti diagram alir yang diberikan oleh Gambar 1. Untuk fungsi yang memberitahukan posisi user dapat menentukan periode setiap lima sekon, tiga sekon dan satu sekon. Location Sensor akan mengirimkan koordinat lokasi setiap sekon. Program akan mengirimkan data koordinat setiap periode. Perangkat lunak beroperasi dengan mengaktifkan layanan GPS yang ada pada mobile station untuk memulai pengambilan data latitude dan longitude melalui data awal koordinat yang akan ditampilkan sambil menunggu perintah user. User harus menekan start agar pembacaan dan logging periodik dapat dilakukan. Program akan terus melakukan logging data sampai diberikan perintah menghentikannya.

\section{Perancangan Pengendali Utama Informasi Lokasi Geografis (PUILG)}

Pengendali Utama merupakan suatu Web Server yang dilengkapi dengan database. Sebagai Web Server digunakan Apache dan untuk database digunakan MySQL. Baik Location Sensor maupun user terminal dapat mengakses Web Server ini dengan browser yang terhubung ke Internet melalui sambungan 3G. Data yang dikirimkan oleh stasiun mobil akan diterima dan dilayani oleh Web Server. Pada awal operasi dilakukan pemutakhiran posisi yaitu melakukan Update Position. Program ini dijalankan untuk melakukan pemutakhiran koordinat pengirim pada tabel yang ada pada database. User mengirimkan data koordinat latitude dan longitude-nya ke server, maka program ini yang kemudian akan menerima data. Data yang diterima akan ditampung untuk sementara waktu. Program akan mulai menjalankan fungsi waktu sejak data diterima oleh program. Waktu yang dicatat terdiri dari hari, bulan, tahun, jam, menit, dan detik untuk menandai setiap data yang dikirimkan. 
Ketika Location Sensor mengirimkan data posisi untuk logging maka posisi baru akan diberikan tanda dengan time stamp dan diisikan ke dalam tabel di database. Data baru tersebut akan menggantikan posisi data lama di dalam tabel. Untuk dapat melakukan koneksi ke dalam database dan melakukan update tabel akan digunakan program yang khusus menjalankan fungsi ini. Dalam proses logging data, Web Server menggunakan data dari dari suatu tabel yang diberinama Tabel Update dan Tabel History. Posisi yang tercatat akan dibandingkan dan jika data berbeda dianggap posisi telah berubah. Terjadi perubahan mengakibatkan dijalankan perhitungan untuk mendapatkan jarak dan kecepatan. Data ini kemudian dimasukkan ke dalam ke dalam tabel history bersama dengan data koordinat dari tabel update dan waktunya.

Proses koneksi ke database dilakukan melalui subprogram yang dirancang untuk keperluan ini. Setiap kali diperlukan akses ke database akan digunakan subprogram ini. Subprogram ini terutama ditujukan untuk melakukan otentikasi dan otorisasi. Pusat Pengendali merupakan sistem yang menpunyai sejumlah fungsi bagi penggunanya. User dapat melakukan pelacakan baik secara real time maupun melihat pergerakan yang telah berlalu. Semua kegiatan dilakukan melalui browser. Fungsi yang dikehendaki dipilih melalui menu yang ditampilkan bagi user tersebut. Terdapat empat pilihan fungsi yaitu Peta Pergerakan Waktu Nyata Benda Bergerak Pertama, Peta Pergerakan Benda Pertama, Peta Pergerakan Waktu Nyata Benda Bergerak Kedua, Peta Pergerakan Benda Kedua. Untuk mengetahui jalur pergerakan benda suatu benda digunakan peta yang berkaitan dengan lokasi.

Posisi benda yang dilacak pada peta akan ditandai oleh suatu penanda (marker). Saat program diaktifkan dengan melakukan pemilihan fitur, suatu pewaktu akan berjalan. Pewaktu ini akan melakukan pemuktahiran marker setiap sesuai dengan spesikasi awal. Peta yang diperoleh dari Google Map akan ditampilkan dan geocoding akan dijalankan. Geocoding merupakan proses untuk melakukan konversi alamat ke koordinat geografis yang dapat digunakan untuk memberikan marker posisi di peta. Proses kebalikan dari geocoding yang disebut sebagai reverse geocoding digunakan untuk mendapatkan alamat yang dapat dibaca oleh user. Geocoding pada Google Map dapat diperoleh melalui melalui Google Maps API dengan menambahkan code pada program berupa objek google.maps.Geocoder. Karena data yang didapatkan berupa koordinat, maka untuk dapat mengkonversi koordinat tersebut menjadi alamat dibutuhkan reverse geocoding. Reverse geocoder dapat menampilkan berbagai jenis alamat sesuai koordinat seperti Negara, provinsi, kota, neighborhoods, alamat jalan, dan kode pos. Setelah geocoding, program akan melakukan koneksi ke database untuk mendapatkan semua data yang ada pada tabel database. Kemudian program akan menandai setiap koordinat baru yang ada di tabel database dengan marker pada peta. Marker akan diupdate setiap interval tertentu. Setiap update marker, maka marker akan menampilkan alamat yang telah di konversi, posisi, dan waktu terbaru.

Fitur Peta Pergerakan digunakan untuk mendapatkan peta pergerakan benda yang telah dilakukannya. Pelacakan pergerakan benda tersebut dilakukan dengan melihat data lokasi yang telah lalu. Peta pergerakan yang ditampilkannya merupakan kumpulan koordinat posisi benda tersebut yang telah diberikan secara real time dan ditandai dengan marker. Peta telah diintegrasikan melalui code peta dari Google Map ke dalam program. Peta yang digunakan merupakan peta dari Google Map. Program akan melakukan geocoding yaitu melakukan proses konversikan alamat ke koordinat geografis, yang dapat digunakan untuk menandai marker atau posisi di peta. Sementara reverse geocoding digunakan untuk melakukan konversikan koordinat geografis ke alamat yang dapat dibaca oleh user. Dalam fitur ini, data yang didapatkan berupa koordinat sehingga perlu dilakukan reverse geocoding. Reverse geocoder dapat menampilkan berbagai jenis alamat seperti Negara, provinsi, kota, neighborhoods, alamat jalan, dan kode pos. Selanjutnya dilakukan koneksi ke database untuk mendapatkan semua data yang ada pada tabel history database. Semua data yang ada pada table akan ditandai dengan marker. Jika ada penambahan data baru pada tabel, maka program akan memberikan marker baru pada peta sesuai koordinat pada tabel. Jika marker pada peta diklik, maka akan menampilkan data alamat jalan, posisi koordinat, waktu dan kecepatan yang telah tersimpan dalam database. 


\section{Perancangan Pengguna Informasi Lokasi Geografis (PILG)}

Saat aplikasi dijalankan akan ditampilkan pilihan benda bergerak yang hendak dilacak. Selanjutnya perlu ditentukan metode pelacakan apakah real-time atau sejarah pergerakan benda tersebut, kemudian dilakukan proses tampilan peta dari Google Maps dan inisialisasi Timer. Posisi pada peta akan ditampilkan sesuai dengan interval yang telah ditetapkan yang umumnya sesuai dengan interval pengiriman kordinat ke server. Saat benda bergerak dipilih akan ditampilkan alamat dan peta yang menunjukkan lokasi benda bergerak yang dilacak. Posisi benda akan ditunjukan oleh marker.

\section{HASIL DAN PEMBAHASAN}

\section{Perangkat}

Untuk penelitian ini digunakan perangkat keras yang mempunyai kemampuan untuk dapat menjalankan fungsi yang telah dirancang. Perangkat keras selain mempunyai fitur yang diperlukan harus cukup ekonomis untuk dipergunakan sebagai alat kerja. Untuk benda bergerak diperlukan perangkat smartphone yang memiliki fitur penerima GPS yang datanya dapat diakses dan dikirimkan melalui jaringan 3G. Smartphone keras yang digunakan sebagai user bergerak dipilih dengan mempertimbangkan harganya. Untuk keperluan penelitian ini dipilih smartphone yang menggunakan Operating System Android. Smartphone yang digunakan mempunyai karakteristik teknis yang dapat menjadikannya sebagai Location Sensor yang handal. Penelitian ini menggunakan smartphone yang mempunyai merek dagang Nexian Journey A890 dan dapat mengakses Internet melalui jaringan 3G UMTS ataupun HSDPA/HSPA. OS yang terpasang adalah Android 2.2.1 (Froyo).

Untuk Pengendali Utama tidak diperlukan perangkat khusus. Baik PC Desktop maupun portable PC dan sebagainya dapat digunakan sebagai server. Bilamana benda bergerak yang harus dilacak cukup banyak, tentu perlu digunakan perangkat keras yang lebih sesuai. Pengendali Utama harus mempunyai kemampuan untuk berfungsi sebagai Web server. Pada penelitian ini digunakan Acer Aspire 4736G yang menggunakan Operating System Windows Vista Home Premium. Pengendali Utama ini terdiri atas Web Server dan Database Server. Sebagai Web Server digunakan Apache dan sebagai database digunakan MySQL.

Sebagai perangkat Location Sensor digunakan Sony Ericsson Xperia U20i dengan Operating System Android, v2.1 yang mempunyai fasilitas koneksi 3G. Pesawat ini juga mempunyai GPS. Sebagai Location Sensor, dia akan dilengkapi dengan program Location Sensor yang dikembangkan untuk keperluan pelacakan dan pemantauan benda bergerak.

\section{Implementasi Pengendali Utama}

Pengendali Utama yang dilengkapi dengan Web Server dan Database serta dengan program aplikasi kendali untuk benda bergerak dijalankan. Bila Pengendali Utama telah berjalan dengan baik, pengendali utama ini siap menerima data dari Location Sensor. Location Sensor secara periodik mengirimkan data untuk disimpan dalam database. Location Sensor GPS harus diaktifkan untuk mengirimkan posisi secara teratur, yaitu dengan menjalankan program Pengendali Utama melalui ikon. Selanjutnya, melalui pilihan "Update Location Data every S", data lokasi akan diterima dan ditampilkan posisi bujur dan lintangnya. Logging dapat dimulai dengan menekan tombol start. Data dikirimkan ke server yang telah siap. Data GPS yang diterima akan disimpan dalam database. Lokasi benda bergerak yang dapat dilacak pergerakannya melalui komunikasi dengan Web Server baik dengan penggunaan PC maupun smartphone. 


\section{Pengguna Statik}

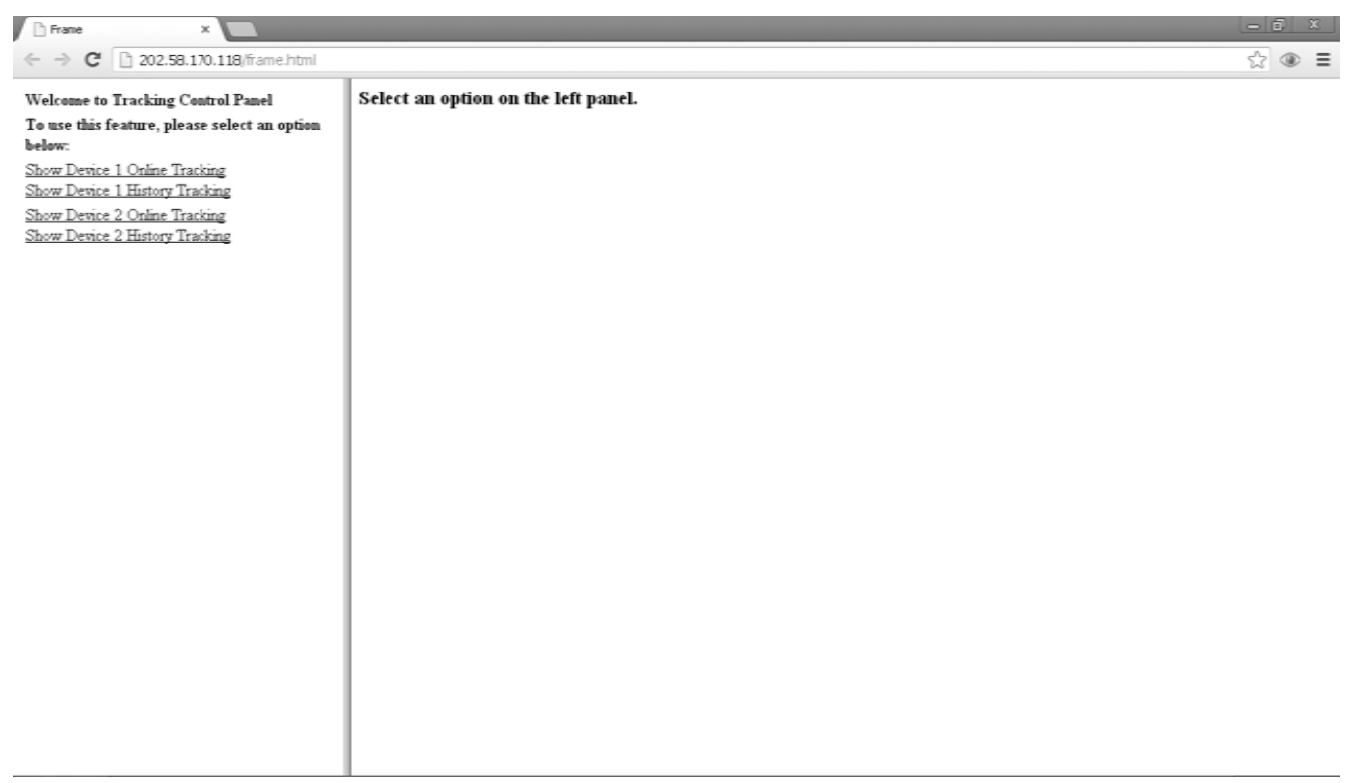

Gambar 2 Tampilan Pengendali Utama

Untuk mendapatkan informasi benda bergerak dalam pemantauan dapat digunakan browser yang diarahkan ke lokasi server ini. Untuk keperluan penelitian telah disediakan IP public untuk digunakan oleh Pengendali Utama sebagai Web Server. Browsing ke alamat tersebut akan memberikan tampilan seperti Gambar 2. Informasi yang dikehendaki dapat dipilih melalui panel pilihan. Bila dipilih Show Device 1 Online Tracking, benda bergerak 1 akan dilacak secara waktu nyata. Pada peta akan terlihat marker benda bergerak 1 dengan data posisi dan waktu.

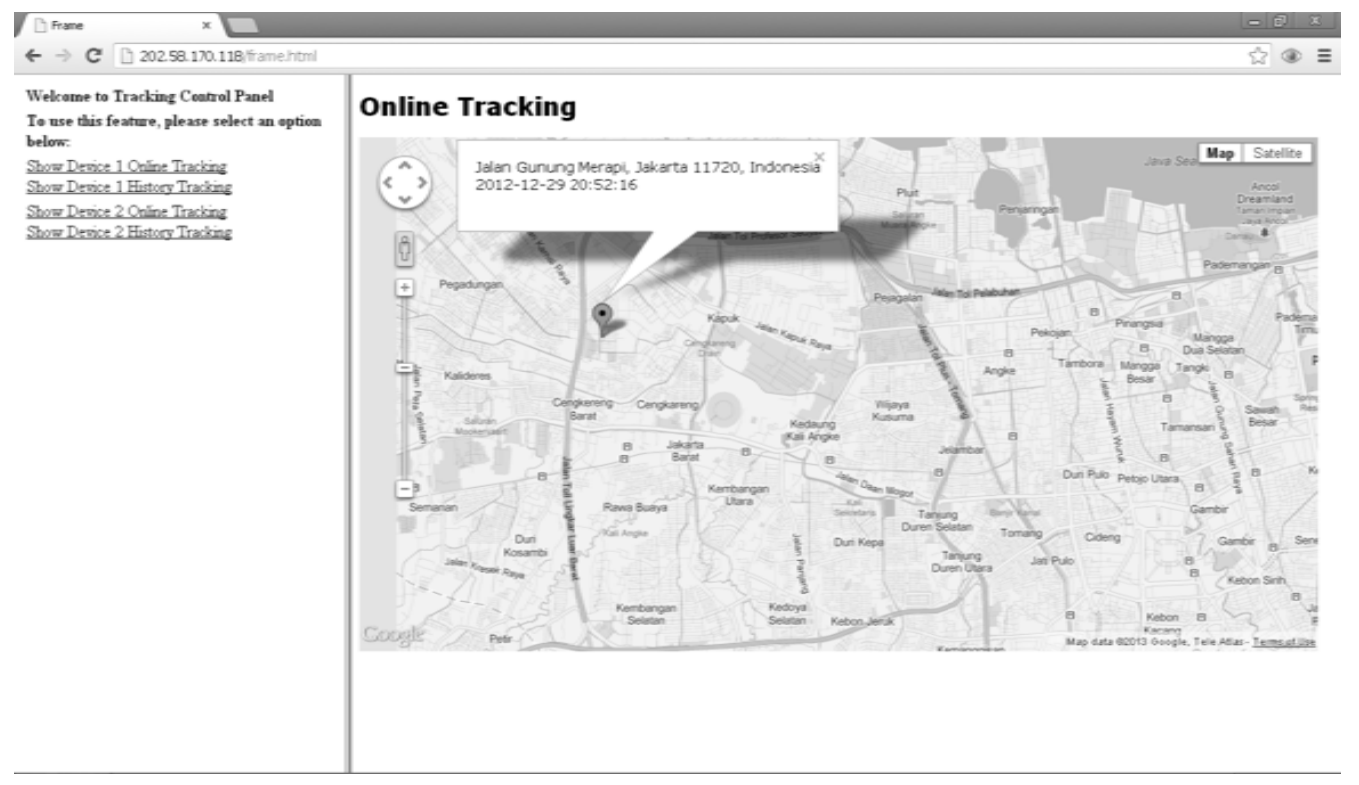

Gambar 3 Tampilan Online Tracking 
Untuk melihat jalur yang telah ditempuh benda 1 digunakan pilihan Show Device 1 History Tracking. Tampilan yang diberikan:

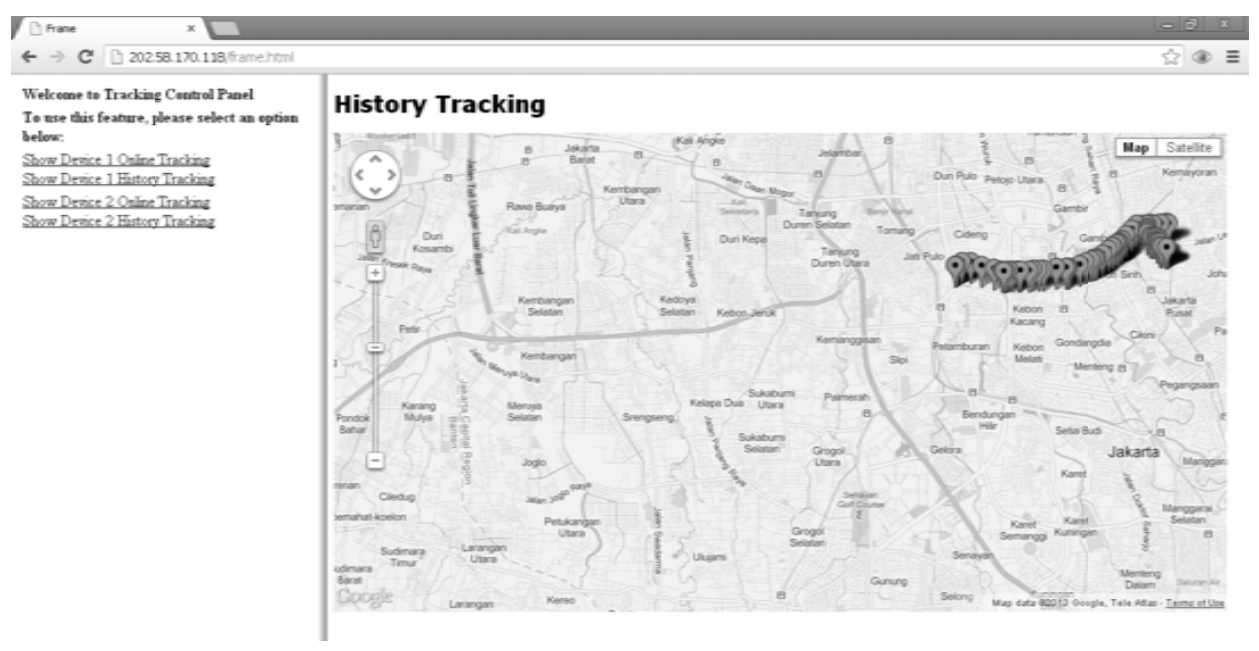

Gambar 4 Tampilan History Tracking

Gambar peta dapat diganti dengan gambar pandangan dari satelit dengan menekan pilihan Satellite yang terletak bagian kanan atas gambar.

\section{Pengguna Bergerak}

Untuk mengetahui lokasi benda bergerak melalui smartphone yang telah dilengkapi program aplikasi khusus yang dikembangkan untuk sistem ini, perangkat harus memiliki koneksi Internet 3G dan mempunyai browser yang dapat mengakses server Pengendali Utama. Program aplikasi untuk menerima informasi Pengendali Utama harus berjalan pada perangkat ini. User harus menentukan benda bergerak yang akan dilacak. Hasilnya akan tampak pada layar perangkat mobil seperti di bawah ini:

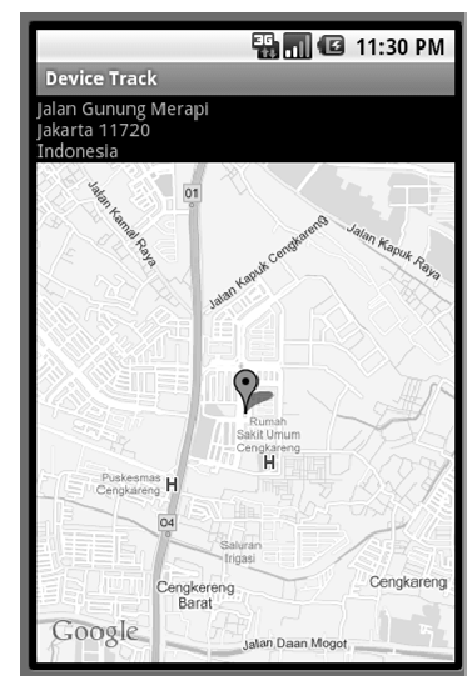

Gambar 5 Tampilan pada User Device 1 


\section{Pelacakan antar Benda Bergerak}

Lebih dari satu benda bergerak dapat dilacak dan saling melacak. Bila tiap benda bergerak mengirimkan koordinat posisi masing-masing ke Pusat Pengendali, mereka dapat dilacak dengan mudah. Mobile User dapat saling mengetahui posisinya sehingga dapat mengetahui keberadaan masing-masing pihak. Untuk keperluan ini dapat digunakan lebih dari satu smartphone. Setiap smartphone harus dapat berfungsi sebagai Location Sensor maupun User dengan sambungan sebagai user yang menggunakan fasilitas 3G maupun HSDPA. Pada pengujian sistem ini, digunakan dua sistem yang masing-masing mempunyai fungsi ganda yaitu sebagai device sebagai pengirim dan penerima, dan menggunakan HSDPA. Tiap sistem bergerak akan mengirim data kordinat. Kemudian masing-masing akan menerima data kordinatnya sendiri ataupun sistem lain. Perangkat akses akan mengakses http://xx.yy.zz.aa/update_position.php untuk melakukan pembaharuan data posisi secara real-time. Untuk melakukan logging track perlu diarahkan ke http://xx.yy.zz.aa/updatelog.php. Data disimpan dalam bentuk tabel tergantung dari perangkat yang digunakan. Pengujian yang dilakukan secara kuantitatif berhasil melakukan tracking, baik track device lain ataupun track device itu sendiri.

\section{SIMPULAN}

Sistem yang dikembangkan untuk memantau maupun melacak benda bergerak ini berbasiskan web dan menggunakan layanan 3G. Sistem yang berbasiskan Web memungkinkan aksesibilitas yang tak terikat pada tempat dan waktu. Layanan 3G memungkinkan sambungan tidak terputus atau always on. Sistem ini dapat digunakan serta dikelola secara mandiri sehingga cocok untuk keperluan pribadi maupun usaha kecil dan menengah. Sistem ini terdiri atas tiga subsistem yaitu Pengirim Bergerak Lokasi Geografis (PBLG) atau (Mobile Geographical Location Sender - MGLS), Pengendali Utama Informasi Lokasi Geografis (PUILG) atau (Main Information Control of Geographical Location MICGL), dan Pengguna Informasi Lokasi Geografis (PILG) atau (Geographical Location Information User- GLIU). PBLG berfungsi sebagai sensor lokasi geografis dan mengambil data lokasi geografis dari GPS untuk kemudian mengirimkannya ke PUILG yaitu pusat pengendali melalui layanan 3G secara periodik. PUILG bekerja sebagai server penerima data yang dikembangkan sebagai Web server. Web server ini dilengkapi dengan aplikasi pengendali yang bertugas mengolah data GPS yang telah dikirimkan oleh PBLG untuk disimpan dalam database dan untuk tampilan visual secara perpusat. Informasi yang telah diolah juga dapat diberikan ke PILG yaitu pengguna lain yang memerlukannya. Pengujian ekperimental menunjukkan bahwa sistem yang dikembangkan ini dapat berfungsi sesuai dengan rancangan. Sistem eksperimental ini diuji untuk kapasitas terbatas yaitu dua unit. Penelitian dapat dilanjutkan untuk benda bergerak lebih dari dua. Perlu juga untuk mempertimbangkan segi estetika serta kemudahan bagi pengguna.

\section{DAFTAR PUSTAKA}

Alde, A., Lange, D., Kadam, P. (2011). GPS-Global Positioning System \& its Applications. International Journal of Functional and Logical Programming.

Chandran, A. (2013). Smartphone Monitoring System. International Journal of Computer Science \& Engineering Technology (IJCSET), 4 (04).

Djuknic, G. M., Richton, R. E. (2001). Geolocation and assisted GPS. Computer, 34(2), 123-125.

Feng, S., Law, C. L. (2002). Assisted GPS and its impact on navigation in intelligent transportation systems. In Proceedings The IEEE 5th International Conference on Intelligent Transportation Systems, 926-931. 
Gruber, V., Schaeffer, L., Silva, J., Restivo, T. (2011). Model for Remote Data Acquisition and Monitoring Integrating Social Media, NTIC's and 3G Cell Phone Networks Applied to Monitoring Small Wind Turbine, Journal of Telecommunication, 7 (1).

Moloo, R.K., Digumber, V.K. (2011). Low-Cost Mobile GPS Tracking Solution. International Conference on Business Computing and Global Information, 516-519.

Schiller, J. (2003). Mobile Communication. Prentice Hall.

Singhal, M., Shukla, A. (2012). Implementation of Location based Services in Android using GPS and Web Services. IJCSI International Journal of Computer Science. (2), 237-242.

Talukder, A. (2010). Mobile Computing. Tata McGraw-Hill

Zandbergen, P. A. (2009). Accuracy of iPhone locations: A comparison of assisted GPS, WiFi and cellular positioning. Transactions in GIS, 13(s1), 5-25. 